\title{
Effects of on-farm composted tomato residues on soil biological activity and yields in a tomato cropping system
}

\author{
Catello Pane ${ }^{1}$, Giuseppe Celano ${ }^{2}$, Alessandro Piccolo ${ }^{3}$, Domenica Villecco ${ }^{1}$, Riccardo Spaccini ${ }^{3}$, Assunta M Palese ${ }^{2}$ \\ and Massimo Zaccardelli $i^{*}$
}

\begin{abstract}
Background: The use of compost may relieve the factors that limit productivity in intensive agricultural systems, such as soil organic matter depletion and soil sickness. Concomitantly, the practice of on-farm composting allows the recycle of cropping green residues into new productive processes.

Results: We produced four vegetable composts by using tomato biomass residues in an on-farm composting plant. The tomato-based composts were assessed for their chemical, microbiological properties, and their effects on soils and plants were evaluated after their application within a tomato cropping system. Compost characteristics affected plant development and productivity through increased nutrient uptake and biostimulation functions. Soil biological activities, including basal respiration, fluorescein diacetate hydrolysis, $\beta$-glucosidase, dehydrogenase, alkaline phosphatase, arylsulphatase, and Biolog community levels of physiological profiles, were differently affected by the on-farm tomato-based composts.

Conclusions: Changes in soil activity and community structure due to compost amendments were related to classes of biomolecules such as polysaccharides and lignin-derived compounds, as revealed by nuclear magnetic resonance (NMR) spectra of compost materials. The nutrient content and fertility potential of composts were positively related to the amount of tomato residues present in the feedstock.
\end{abstract}

Keywords: Carbon structures; C-CPMAS-NMR; Soil microbial activity; Tomato yield; Vegetable compost

\section{Background}

On-farm composting is an efficient, cost-effective and environmentally safe biological process for the recycling of residual agricultural biomasses into new cropping production cycles [1]. It is a simple technology consisting of user-friendly small composting plants equipped with tools already available on a farm, where undegraded organic biomasses are transformed and stabilized through an aerobic biooxidation [2]. On-farm composting substantially contributes to solve the problem of disposing agricultural biomasses and vegetable feedstock and concomitantly provides the farmer with a self-supply of quality compost for the improvement of agricultural productivity.

\footnotetext{
* Correspondence: massimo.zaccardelli@entecra.it

${ }^{1}$ Consiglio per la Ricerca in Agricoltura e l'Analisi dell'Economia Agraria, Centro di Ricerca per l'Orticoltura, via dei Cavalleggeri 25, I-84098 Pontecagnano, SA, Italy

Full list of author information is available at the end of the article
}

Loss of soil quality is related to soil organic matter (SOM) depletion that is increased by continuous cropping without rotations, frequent soil tillage and large use of both inorganic chemical fertilizers and non-selective pesticides. Intensively exploited soils need an external supply of stabilized organic matter, such as compost, in order to counteract progressive SOM decline. Soil compost amendments contribute to the general soil quality recovery and improvement of plant growing conditions [3] by providing numerous ecosystem services, including replenishment of soil carbon stocks, increase of microbial activity and biodiversity and restoration of plant nutrition and natural soil suppressiveness [4].

In some developed horticultural areas of Southern Italy, significant amounts of agricultural wastes, such as cropping residues, unmarketable products and vegetable processing leftovers, are currently produced. They represent an

\section{然}

(c) 2015 Pane et al.; licensee Springer. This is an Open Access article distributed under the terms of the Creative Commons Attribution License (http://creativecommons.org/licenses/by/4.0), which permits unrestricted use, distribution, and reproduction in any medium, provided the original work is properly credited. 
important source of organic matter to be composted and returned to soil. Tomato (Solanum lycopersicum) green wastes from greenhouse systems produce about $15 \mathrm{t} \mathrm{ha}^{-1} \mathrm{y}^{-1}$ of fresh plant residues and are among the most abundant biomasses suitable for transformation in compost.

López-Pérez et al. [5] proposed the direct incorporation of tomato residues into soil as a green biofumigating practice, but it failed in controlling nematode Meloidogyne incognita infestation. Risks of plant pathogen dissemination and phytotoxicity hazards are eliminated when an effective sanitation of tomato wastes is achieved through a thermophilic composting process before amendment to soils [6,7]. Although some studies focused on tomato plant composting [8,7], little attention has been so far paid to assess the agronomic effectiveness of the produced compost. By assuming that on-farm composting of tomato plant wastes is the best sustainable practice to improve soil quality, our aim was to investigate (i) the effects of field compost amendments on tomato yields and resulting soil biological characteristics, (ii) the quality of on-farm composts from tomato plant residues in comparison with a commercial organic waste compost, and (iii) the molecular biomarkers which could differentiate tomato-based composts according to different amounts of tomato and other composted additives.

\section{Methods}

\section{On-farm composting}

Tomato plant residues were used as main compost feedstock, while escarole (Cichorium endivia) residues, wood chips and mature compost as starter were also added. The four composting piles had the following compositions: $\mathrm{C}_{1}, 17.5 \%$ tomato, $15.5 \%$ escarole residues, $65 \%$ woodchips and $2 \%$ mature compost as starter; $C_{2}, 25 \%$ tomato residues, $13 \%$ escarole residues, $60 \%$ woodchips and $2 \%$ mature compost as starter; $\mathrm{C}_{3}, 37 \%$ tomato residues, $11 \%$ escarole residues, $50 \%$ woodchips and $2 \%$ mature compost as starter; and $\mathrm{C}_{4}, 50 \%$ tomato residues, $48 \%$ woodchips and $2 \%$ mature compost as starter. All four raw piles were set up with an initial $\mathrm{C} / \mathrm{N}$ ratio of about 30 in order to hasten the composting switch-on. The mature compost starter was a 2-year-old $\mathrm{C}_{\mathrm{OW}}$, purchased at Gesenu (Perugia, Italy). The on-farm composting process was carried out in four parallel static piles of about $6 \mathrm{~m}^{3}$ in volume, under forced aeration, through an overall 90-day cycle that included a thermophilic and a mesophilic phase, followed by a final curing period. The on-farm composting system was assembled by using currently available tools in common farms. Mechanical aeration was provided by air injection through a net of tubes connected to a blower $(0.75 \mathrm{KW})$ that was periodically activated ( 5 min every $3 \mathrm{~h}$ ) with an electronic timer. Pile wetting was achieved through a PVC irrigation system, manually activated on demand (when $\mathrm{RH}<50 \%$ ). Composting temperatures were measured by thermo-sensors placed in the pile core at $15 \mathrm{~cm}$ from the pile bottom.

\section{Results}

\section{On-farm compost characteristics}

Chemical features of feedstock and composts are reported in Tables 1 and 2. Compost samples exhibited a sub-alkaline $\mathrm{pH}$ value (>8.0). The levels of electrical conductivity and macronutrients, including $\mathrm{N}, \mathrm{P}$ and $\mathrm{K}$, increased with the amount of tomato residues used, while, in all cases, the heavy metal contents detected were below risk levels according to Italian laws.

The ${ }^{13} \mathrm{C}$ cross polarization magic angle spinning nuclear magnetic resonance $\left({ }^{13} \mathrm{C}\right.$-CPMAS-NMR) spectra of compost materials were characterized by strong signals in the O-alkyl-C (61 to $110 \mathrm{ppm}$ ) region, revealing a molecular composition dominated by carbohydrates (Figure 1). In fact, the signals related to O-Alkyl-C components represent most of the organic carbon, accounting for $42.5 \%$ up to $56.3 \%$ of the total area of the nuclear magnetic resonance (NMR) spectra. The different resonances in the $\mathrm{O}$-alkyl-C region are currently assigned to monomeric units in oligo and polysaccharide chains of plant tissue [9]. The intense signal around $72 \mathrm{ppm}$ corresponds to the overlapping resonances of carbon 2, 3 and 5 in the pyranoside structure in cellulose and some hemicelluloses, whereas the signal at $106 \mathrm{ppm}$ is assigned to the anomeric carbon 1 of the glucose unit in cellulose [10]. The shoulders localized around 62 to 65 and 84 to $88 \mathrm{ppm}$ results from carbon 6 and 4 of monomeric units, respectively. The low-field resonances (higher chemical shift) of each pair indicate the presence of crystalline forms of cellulose, while the high-field ones (lower chemical shift) are assigned to either amorphous

Table 1 Chemical determinations on plant residues used as composting feedstock

\begin{tabular}{|c|c|c|c|c|c|c|c|c|c|c|c|c|}
\hline \multirow[b]{2}{*}{ Residues } & \multicolumn{12}{|c|}{ Chemical features } \\
\hline & $\mathrm{N}(\%)$ & $\mathrm{P}(\%)$ & K (\%) & Ca (\%) & $\mathrm{Mg}(\%)$ & $\mathrm{Na}(\%)$ & Mn (ppm) & Cd (ppm) & $\mathrm{Cr}(\mathrm{ppm})$ & $\mathrm{Cu}$ (ppm) & $\mathrm{Pb}$ (ppm) & $\mathrm{Zn}$ (ppm) \\
\hline Tomato & 2.1 & 0.0062 & 3.04 & 1.46 & 0.20 & 0.57 & 140.94 & 0.253 & 32.33 & 55.81 & 1.06 & nd \\
\hline Escarole & 3.8 & 0.0154 & 3.09 & 1.01 & 0.17 & 0.33 & 35.71 & 0.166 & 4.31 & 112.75 & nd & nd \\
\hline Woodchip & 1.0 & 0.0004 & 0.06 & 0.39 & 0.06 & 0.12 & 7.96 & 0.143 & 6.71 & 5.42 & nd & nd \\
\hline
\end{tabular}

nd, not detected. 
Table 2 Main chemical quality characteristics of the composts

\begin{tabular}{|c|c|c|c|c|c|c|c|c|c|c|c|c|c|c|}
\hline \multirow[b]{2}{*}{ Composts } & \multicolumn{14}{|c|}{ Chemical features } \\
\hline & $\mathrm{pH}$ & $\begin{array}{c}\mathrm{EC} \\
\left(\mathrm{mS} \mathrm{cm}^{-1}\right)\end{array}$ & $\begin{array}{c}N \\
(\%)\end{array}$ & $\begin{array}{c}\mathrm{P} \\
(\%)\end{array}$ & $\begin{array}{c}\mathrm{K} \\
(\%) \\
\end{array}$ & $\begin{array}{l}\mathrm{Ca} \\
(\%)\end{array}$ & $\begin{array}{l}M g \\
(\%)\end{array}$ & $\begin{array}{l}\mathrm{Na} \\
(\%)\end{array}$ & $\begin{array}{c}\mathrm{Mn} \\
\text { (ppm) }\end{array}$ & $\begin{array}{c}\mathrm{Cd} \\
(\mathrm{ppm})\end{array}$ & $\begin{array}{c}\mathrm{Cr} \\
\text { (ppm) }\end{array}$ & $\begin{array}{c}\mathrm{Cu} \\
(\mathrm{ppm})\end{array}$ & $\begin{array}{c}\mathrm{Pb} \\
\text { (ppm) }\end{array}$ & $\begin{array}{c}\mathrm{Zn} \\
\text { (ppm) }\end{array}$ \\
\hline$C_{1}$ & 8.40 & 2.69 & 1.25 & 0.023 & 1.46 & 3.87 & 1.02 & 0.20 & 328.99 & 0.47 & 34.80 & 40.16 & 4.17 & 64.62 \\
\hline$C_{2}$ & 8.19 & 4.12 & 1.23 & 0.020 & 1.21 & 5.32 & 1.25 & 0.15 & 297.42 & 0.51 & 34.84 & 55.68 & 4.58 & 108.50 \\
\hline$C_{3}$ & 8.12 & 5.09 & 1.41 & 0.045 & 1.99 & 4.43 & 1.18 & 0.22 & 415.18 & 0.45 & 57.96 & 52.96 & 4.87 & 140.40 \\
\hline$C_{4}$ & 8.31 & 8.92 & 1.52 & 0.048 & 1.92 & 4.90 & 1.23 & 0.15 & 260.96 & 0.58 & 17.99 & 45.02 & 3.09 & 57.06 \\
\hline Cow & 8.93 & 5.07 & 2.72 & 0.029 & 1.18 & 6.58 & 0.40 & 0.27 & 427.30 & 0.30 & 16.05 & 45.98 & 28.15 & 247.40 \\
\hline Legal limits & & & & & & & & & & $<1.5$ & $<100$ & $<150$ & $<140$ & $<500$ \\
\hline
\end{tabular}

cellulose or hemicellulose structures [11]. The various O-alkyl regions could also include signals related to carbon in the propylic side chain of lignin molecules, whose smaller resonances around 62, 72 and $82 \mathrm{ppm}$, could be masked by the predominance of polysaccharides. Besides the signals usually assigned to cellulose, the spectra of different composts revealed two additional resonances around 98 and $101 \mathrm{ppm}$. These signals may be related to the di-O-alkyl-C of, respectively, monomeric units of simple carbohydrates [10] and those of either hemicellulose or pectic polysaccharide chains contained in cell walls of tomato plants, such as $\alpha-1,5$ arabinan, $\beta-1,4$ galactan and $\alpha-1,4$ galacturonan [12]. The broad peak in the Alkyl-C region (0 to $45 \mathrm{ppm})$ of the NMR spectra indicated the presence of alkyl chains $\left(-\mathrm{CH}_{2}-\right.$ groups) derived mainly from various lipid compounds, plant waxes and polyesters. The signal at $56 \mathrm{ppm}$ is associated with either the methoxyl substituent on the aromatic rings of guaiacyl and syringyl units in lignin structures or the C-N bonds in amino acid moieties [9]. Moreover, this O-alkyl region may also include the resonances related to ether and epoxy groups of plant

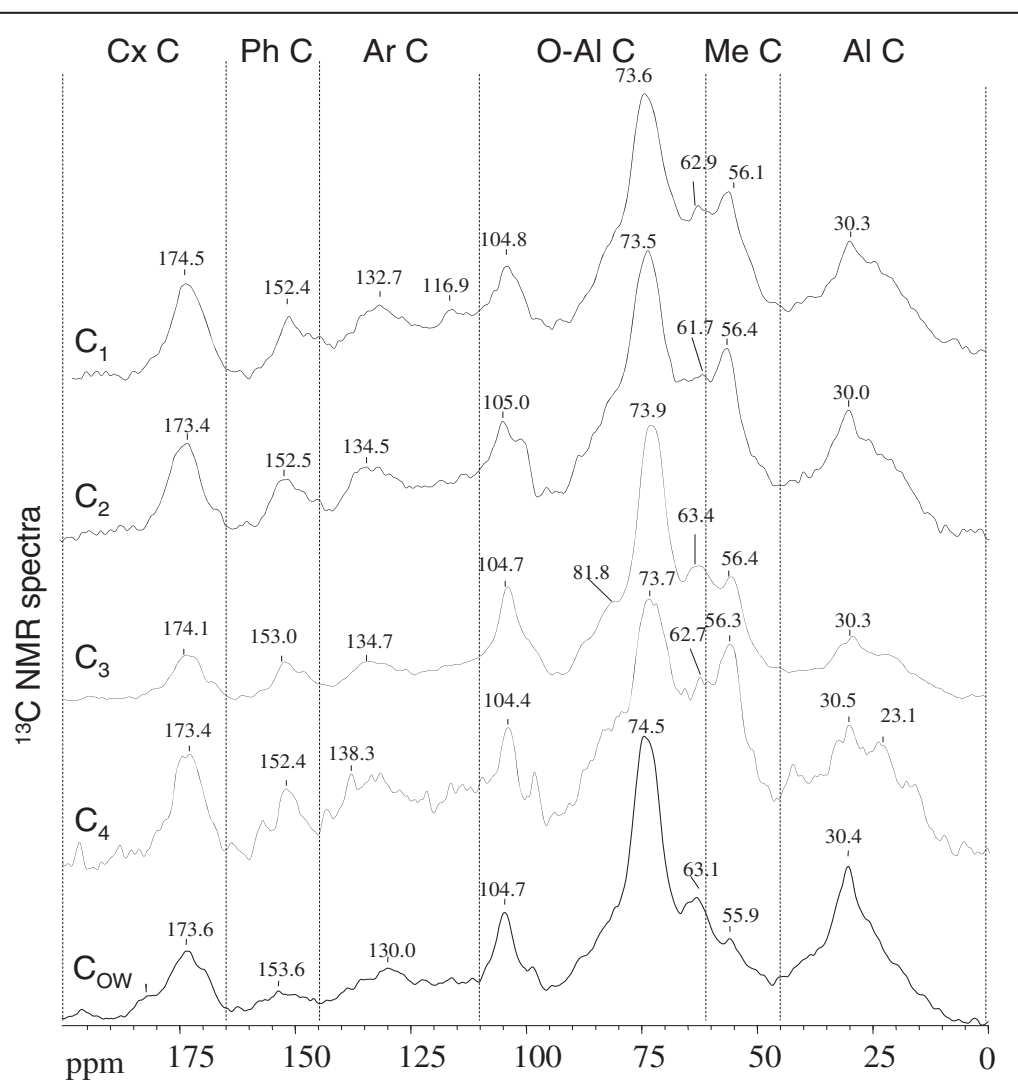

Figure $1{ }^{13} \mathrm{C}$-CPMAS-NMR spectra of compost $\left(\boldsymbol{C}_{1}\right.$ to $\left.\boldsymbol{C}_{\text {ow }}\right)$ samples. Vertical lines delimitate six different spectral regions: aliphatic and aromatic carboxyl C (Cx C, 190 to 166 ppm); oxygen-substituted aromatic C from lignin and non-hydrolyzable tannins, phenolic and O-aryl (Ph C, 165 to 146 ppm); unsubstituted and alkyl-substituted aromatic C, aryl ( $\operatorname{ArC}, 145$ to 111 ppm); anomeric C and di-Oalkyl and oxidized and/or carbohydrate C, O-alkyl (O-Al C, 110 to 61 ppm); methoxyl/N-alkyl (Me C, 60 to 46 ppm); and aliphatic C, alkyl (Al C, 45 to 0 ppm). 
Table 3 Relative distribution (\%) of signal area over chemical shift regions (ppm) in ${ }^{13} \mathrm{C}$-CPMAS-NMR spectra of the composts

\begin{tabular}{|c|c|c|c|c|c|c|}
\hline & $\begin{array}{l}\text { Carboxylic-C } \\
195 \text { to } 166 \text { ppm }\end{array}$ & $\begin{array}{l}\text { Phenolic-C } \\
165 \text { to } 146 \text { ppm }\end{array}$ & $\begin{array}{l}\text { Aromatic-C } \\
145 \text { to } 111 \mathrm{ppm}\end{array}$ & $\begin{array}{l}\text { O-Alkyl-C } \\
110 \text { to } 61 \mathrm{ppm}\end{array}$ & $\begin{array}{l}\mathrm{CH}_{3} \mathrm{O} / \mathrm{C}-\mathrm{N} \\
60 \text { to } 46 \mathrm{ppm}\end{array}$ & $\begin{array}{l}\text { Alkyl-C } \\
45 \text { to } 0 \text { ppm }\end{array}$ \\
\hline$C_{1}$ & 8.56 & 4.79 & 13.18 & 43.41 & 11.82 & 8.24 \\
\hline$C_{2}$ & 7.46 & 4.62 & 13.12 & 44.82 & 12.08 & 17.90 \\
\hline$C_{3}$ & 5.61 & 4.15 & 11.50 & 52.97 & 11.39 & 14.37 \\
\hline$C_{4}$ & 6.25 & 3.75 & 14.55 & 42.41 & 13.05 & 19.99 \\
\hline Cow & 8.36 & 3.26 & 13.08 & 52.49 & 9.22 & 24.84 \\
\hline
\end{tabular}

biopolyesters. In the aromatic/olefinic- $\mathrm{C}$ region (111 to $145 \mathrm{ppm})$, the different resonances around 116 and $130 \mathrm{ppm}$ are related to unsubstituted and C-substituted phenyl carbon pertaining to lignin monomers of guaiacyl and syringyl units [11] as well as to the ring components of plant polyphenols. The signals shown in the specific phenolic aromatic region (146 to $165 \mathrm{ppm}$ )

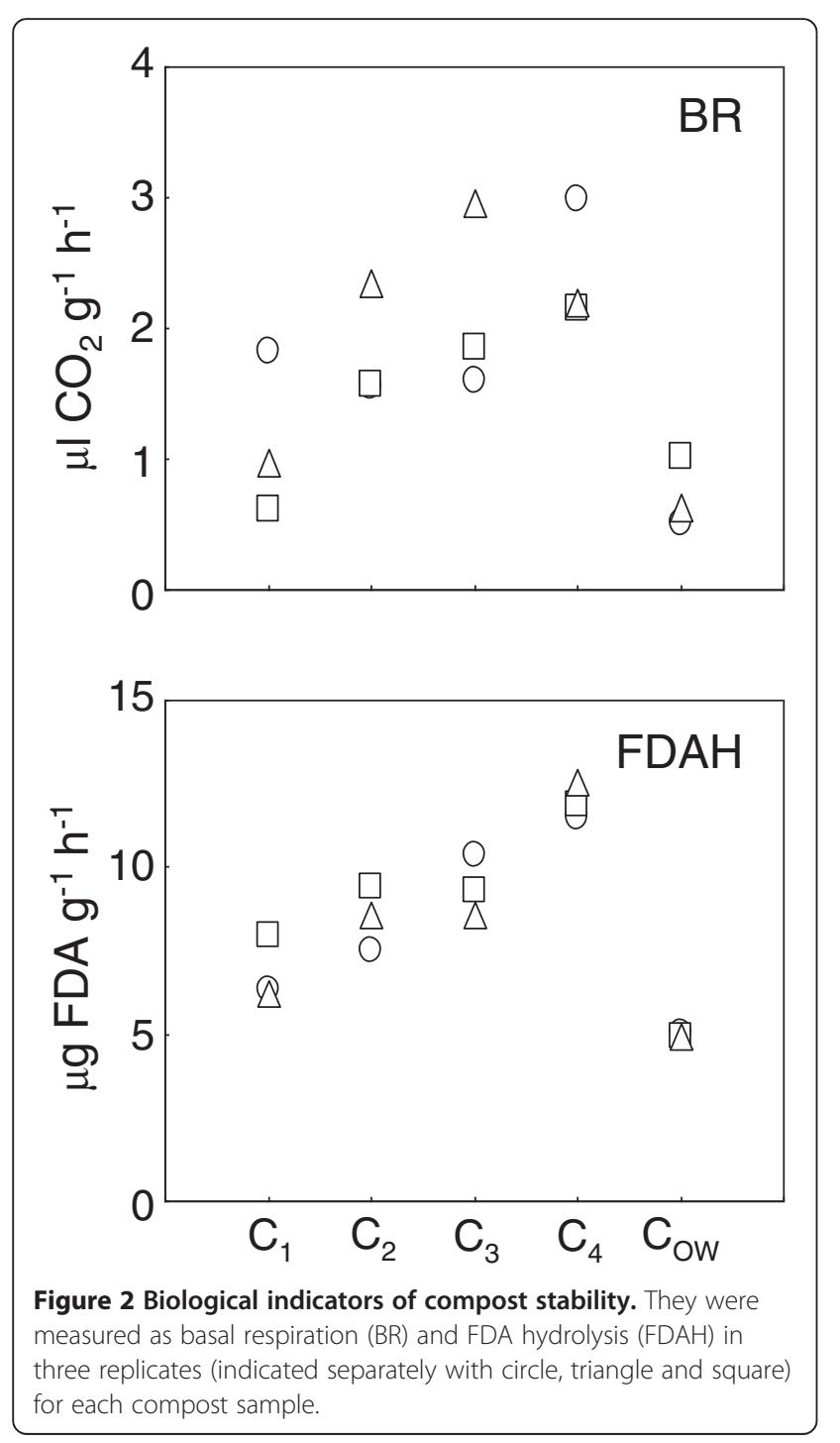

confirmed the presence of O-substituted ring carbon derived from different aromatic structures. In fact, the resonances included in the 148 - to 155 - ppm range are usually assigned to carbon 3,4 and 5 in the aromatic ring in lignin components, carbon 3 and 5 being coupled to the corresponding methoxyl substituents. Conversely, the peaks found at 143 and $157 \mathrm{ppm}$ in the NMR spectra of $\mathrm{C}_{4}$ suggest the significant incorporation of polyphenol derivatives originating from tomato residues [10]. Finally, the broad signal at $173 \mathrm{ppm}$ indicates the contribution of carbonyl groups of aliphatic acids and amino acid moieties in all the compost materials. The ${ }^{13} \mathrm{C}$-CPMAS-NMR signals exhibited differences among composts (Table 3). The aliphatic alkyl $\mathrm{C}$ region (45 to $0 \mathrm{ppm}$ ) was most evident in commercial organic-waste compost $\left(\mathrm{C}_{\mathrm{OW}}\right)$, followed by $\mathrm{C}_{1}$ and $\mathrm{C}_{4}$ then $\mathrm{C}_{2}$ and $\mathrm{C}_{3}$. The $\mathrm{CH}_{3} \mathrm{O} / \mathrm{C}-\mathrm{N}$ region (60 to $46 \mathrm{ppm}$ ) was slightly variable among composts. The O-alkyl $\mathrm{C}$ region (110 to $61 \mathrm{ppm}$ ) was largely developed in $C_{3}$, whereas it was less noticeable in the remaining samples. Moreover, the intensity of the region associated with aromatic C (145 to $111 \mathrm{ppm}$ ) was large for $\mathrm{C}_{4}$, decreased in the order passing from $\mathrm{C}_{1}$ and $\mathrm{C}_{2}$. Conversely, the spectral regions associated to phenolic $\mathrm{C}$ (165 to $146 \mathrm{ppm}$ ) was relevant in $\mathrm{C}_{2}$ and limited in $\mathrm{C}_{\mathrm{OW}}$, while that for carboxyl $\mathrm{C}$ (195 to $166 \mathrm{ppm}$ ) was smaller in $\mathrm{C}_{3}$ than for the rest of the other composts. Fluorescein diacetate hydrolytic (FDAH) activity resulted as the largest for $\mathrm{C}_{4}$ and was followed, in the

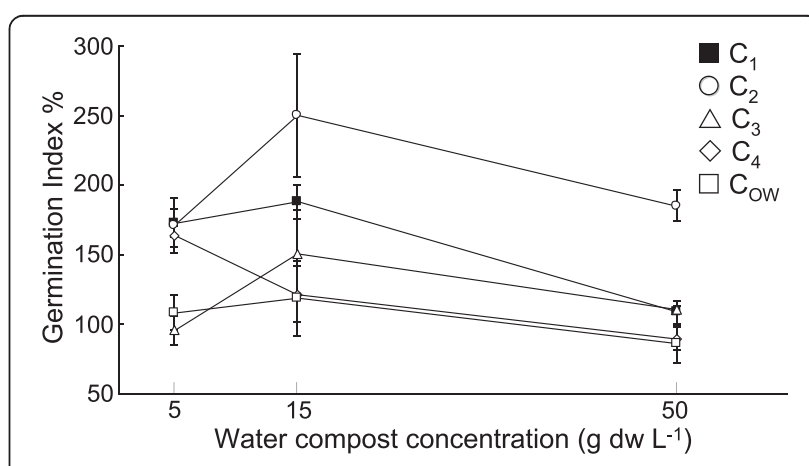

Figure 3 Evaluation of the cress germination index on water extracts of composts. $C_{1}$ to $C_{0 w}$ samples were assayed at high, medium and low concentrations (50, 16.6 and $5 \mathrm{~g} \mathrm{I}^{-1}$, respectively). 
Table 4 Effects of soil treatments on tomato cropping response

\begin{tabular}{|c|c|c|c|c|c|c|c|}
\hline & \multicolumn{7}{|c|}{ Tomato system response } \\
\hline & \multirow{2}{*}{$\begin{array}{l}\text { Green biomass } \\
\quad\left(\mathrm{Q} \mathrm{ha} \mathrm{ha}^{-1}\right)\end{array}$} & \multicolumn{3}{|c|}{ Yield } & \multicolumn{3}{|c|}{ Quality of berries } \\
\hline & & Total (t ha $\left.{ }^{-1}\right)$ & Marketable $\left(\mathrm{t} \mathrm{ha}^{-1}\right)$ & Discard $\left(\mathrm{t} \mathrm{ha} \mathrm{a}^{-1}\right)$ & Weight (g) & $\mathrm{pH}$ & Optical residue $\left({ }^{\circ} \mathrm{Bx}\right)$ \\
\hline$\overline{C_{1}}$ & $98.05 b c$ & 66.6 de & $62.5 c$ & $8.51 \mathrm{a}$ & $75.8 \mathrm{a}$ & $4.15 \mathrm{a}$ & $3.02 \mathrm{a}$ \\
\hline$C_{2}$ & $117.08 \mathrm{~b}$ & $83.3 \mathrm{bcd}$ & $75.7 \mathrm{bc}$ & $10.70 \mathrm{a}$ & $84.3 \mathrm{a}$ & $4.09 \mathrm{a}$ & $3.37 \mathrm{a}$ \\
\hline$C_{3}$ & $128.13 \mathrm{~b}$ & 73.6 cde & $69.6 \mathrm{bc}$ & $8.72 \mathrm{a}$ & $78.4 \mathrm{a}$ & $4.15 \mathrm{a}$ & $2.98 \mathrm{a}$ \\
\hline $\mathrm{C}_{4}$ & 149.38 a & $93.1 \mathrm{abc}$ & $88.1 \mathrm{ab}$ & $13.80 \mathrm{a}$ & 86.9 a & $4.19 \mathrm{a}$ & $3.71 \mathrm{a}$ \\
\hline Cow & $91.81 \mathrm{c}$ & $60.6 \mathrm{e}$ & $55.1 \mathrm{C}$ & $8.35 \mathrm{a}$ & $82.0 \mathrm{a}$ & $4.03 \mathrm{a}$ & $3.03 \mathrm{a}$ \\
\hline$M_{N R}$ & 144.24 a & $105.8 \mathrm{a}$ & $101.2 \mathrm{a}$ & $12.1 \mathrm{a}$ & 74.3 a & $4.31 \mathrm{a}$ & $3.44 a$ \\
\hline$M_{S R}$ & 148.61 a & $100.6 \mathrm{ab}$ & 96.7 a & $12.2 \mathrm{a}$ & 74.9 a & $4.20 \mathrm{a}$ & $3.56 \mathrm{a}$ \\
\hline CTRL & $109.72 b c$ & 73.0 cde & $68.2 b c$ & $12.4 \mathrm{a}$ & $81.0 \mathrm{a}$ & $4.17 \mathrm{a}$ & $2.81 \mathrm{a}$ \\
\hline
\end{tabular}

Different letters indicate significant differences (ANOVA, Duncan's test, $P \leq 0.05$ ).

order, by $\mathrm{C}_{3}, \mathrm{C}_{2}$ and $\mathrm{C}_{1}$, while $\mathrm{C}_{\mathrm{OW}}$ showed the smallest value (Figure 2). Similarly, basal respiration (BR) was the greatest for the $\mathrm{C}_{4}$ compost.

\section{Phytotoxicity of on-farm composts}

On-farm compost water extracts proved variable effects on cress germination index percentage (GI\%) (Figure 3). In fact, while $\mathrm{C}_{2}$ showed the lowest toxicity, the one observed for $\mathrm{C}_{\mathrm{OW}}$ was the largest. Germination was

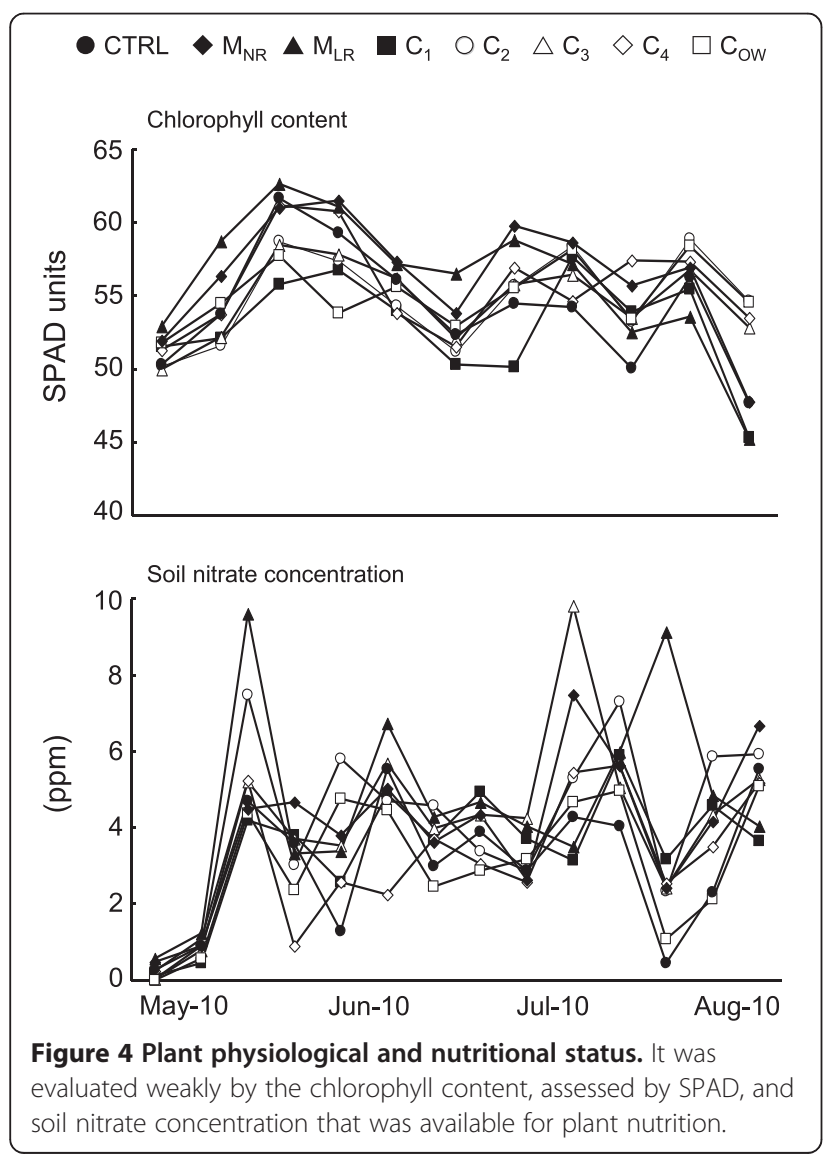

increasingly repressed by on-farm compost extracts passing from $\mathrm{C}_{1}$ to $\mathrm{C}_{4}$. In the case of $\mathrm{C}_{1}, \mathrm{C}_{2}$ and $\mathrm{C}_{3}$ extracts, the percent cress $\mathrm{GI} \%$ showed a singular pattern, since it significantly increased at an intermediate concentration, while it dropped back down at the lowest concentration. $\mathrm{C}_{4}$ and $\mathrm{C}_{\mathrm{ow}}$ extracts exhibited a dosedependent behaviour.

\section{Crop response to soil amendment with on-farm composts} The commercial and total yields of $\mathrm{C}_{4}$-treated plots were larger by about $20 \mathrm{t} \mathrm{ha}^{-1}$ than for control plots. The remaining on-farm composts $\left(C_{1}, C_{2}\right.$ and $\left.C_{3}\right)$ led to increasing yields that did not differ significantly from those of untreated plots (Table 4). On-farm composts did not show any phytotoxic symptoms, whereas $\mathrm{C}_{\mathrm{OW}}$ that induced the lowest yield caused a slight growth reduction in the early phases of the crop cycle. No significant differences were observed regarding the discarded production. Plant weight was significantly affected by treatments (Table 4). Similarly, berry quality (single weight, $\mathrm{pH}$ and optical residue) was not significantly affected by treatments, nor was plant physiologically status, which was generally observed to be at standard levels, as confirmed by chlorophyll content, likely sustained by nitrate availability throughout the tomato cycle (Figure 4). All raw compost eluates showed in vitro antibiosis against Fusarium oxysporum f. sp. lycopersici (data not shown).

\section{Effects of on-farm composts on soil properties}

In order to assess the impact of compost amendments on soil properties, a set of biological indicators was used. The BR analyses showed an initial burst of activity due to compost amendments that approached the control over time. Levels of BR were in the following order: $\mathrm{C}_{\mathrm{OW}}, \mathrm{C}_{4}$, $C_{1}, C_{2}$ and $C_{3}$ (Figure 5). Soil enzymatic activities that were also significantly activated by composts showed a durable effect during the whole incubation time (Figure 5). The largest values of FDAH, $\beta$-glucosidase ( $\beta$ GLU) and 

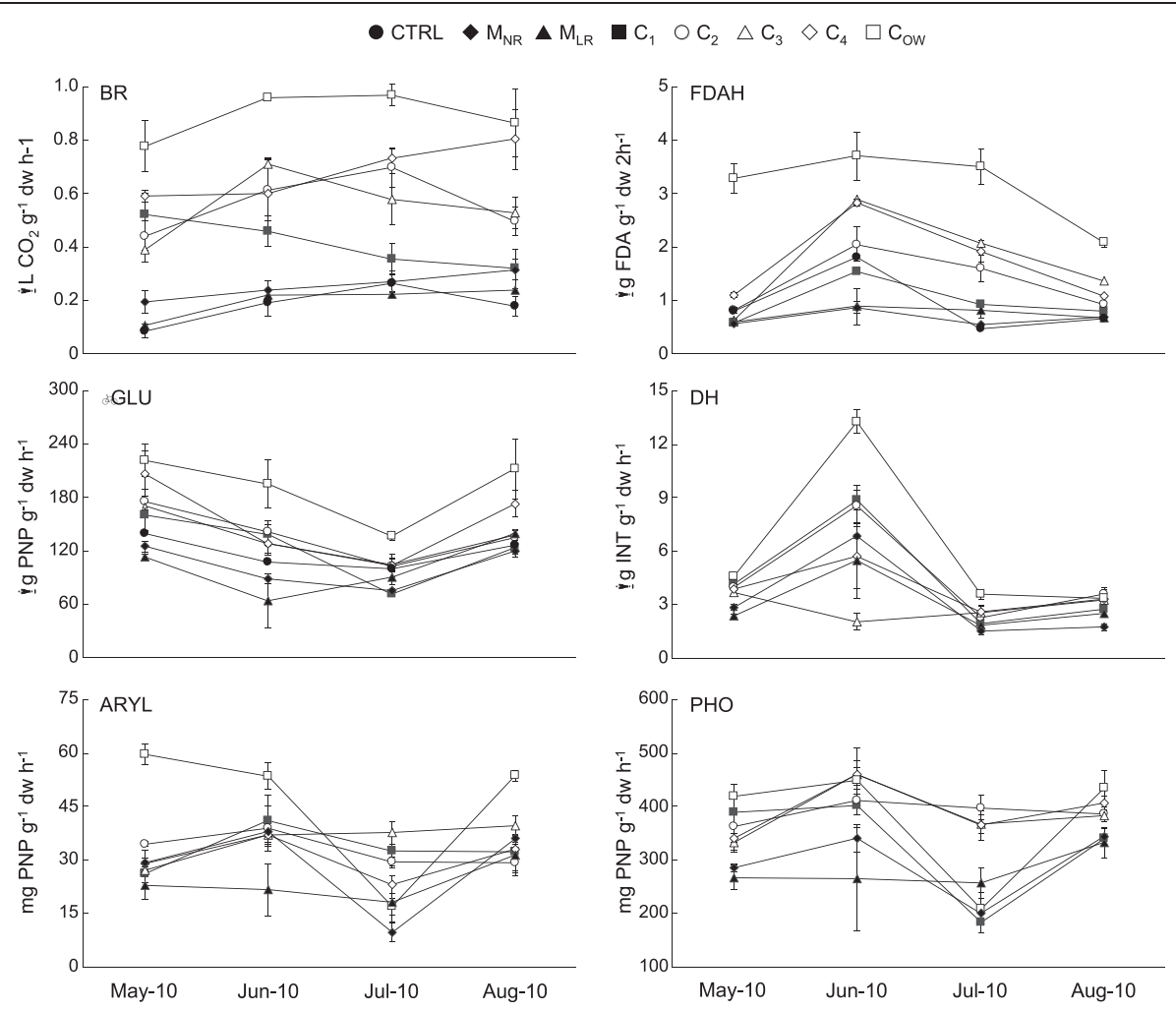

Figure $\mathbf{5}$ Changes over time in soil BR, FDAH, $\beta G L U, D H, A R Y L$ and PHO. They were assessed monthly in experimental plots after soil treatments.

dehydrogenase (DH) activities were observed in soils amended with the municipal waste compost. Similarly, arylsulphatase (ARYL) and alkaline phosphatase (PHO) activities that resulted in large values for soils treated with tomato-based compost also showed peaks of activity only at the later stage of incubation (Figure 5). $\beta$ GLU and DH, on the other hand, showed almost constant values over the whole incubation time.

The relationships between carbon distribution in compost and soil enzymatic activities during the incubation period were elucidated by calculating the Pearson's coefficient between these two variables. In fact, coefficient profiles for cumulative regressions were generated: interestingly, it was found that polysaccharides, as well as degradation forms of lignin, produced the most significant correlations (Figure 6). Average well colour development (AWCD) and Shannon index $\left(\mathrm{H}^{\prime}\right)$ temporal shifts showed that on-farm composts significantly increased a progressive functional diversity passing from $C_{1}$ to $C_{4}$ (Figure 7). The soil amended with municipal waste compost showed an intermediate behaviour as compared to that of $\mathrm{C}_{2}$. However, the activity enhanced by compost treatments slightly, but substantially, regressed at the end of incubation time.

To show differences in microbial community structure, levels of carbon source catabolism were subjected to principal component analysis (PCA). The PC1 explained $61.39 \%$ of the variance, while $\mathrm{PC} 2$ explained only $12.53 \%$ (Figure 7). Along the PC1 axis, the compostamended plots clustered together and resulted different from the unamended plots, though the $\mathrm{C}_{4}$ cluster was most distant from the rest. In general, the communities in each plots grouped closely, thus indicating a little influence from sampling time. PC1-variable correlation resulted as significant $(R>0.60)$ and negative for all carbon sources (factor loadings), with the exception of hydroxy benzoic acid, $\mathrm{d}$-malic acid, l-asparagine and phenylethylamine, that were not significantly correlated. Instead, only l-arginine carbon source resulted as significantly correlated $(R=0.67)$ with $\mathrm{PC} 2$.

\section{Discussion}

\section{Chemical characteristics of agricultural composts and stability}

On-farm composting of crop residues is an effective method to produce highly humified organic matter from agricultural green wastes, while they are usefully recycled according to a concept of agricultural sustainability [13]. Moreover, these particular feedstocks significantly influenced compost properties and their ability to condition soil and plant response. 


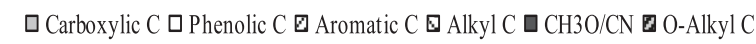

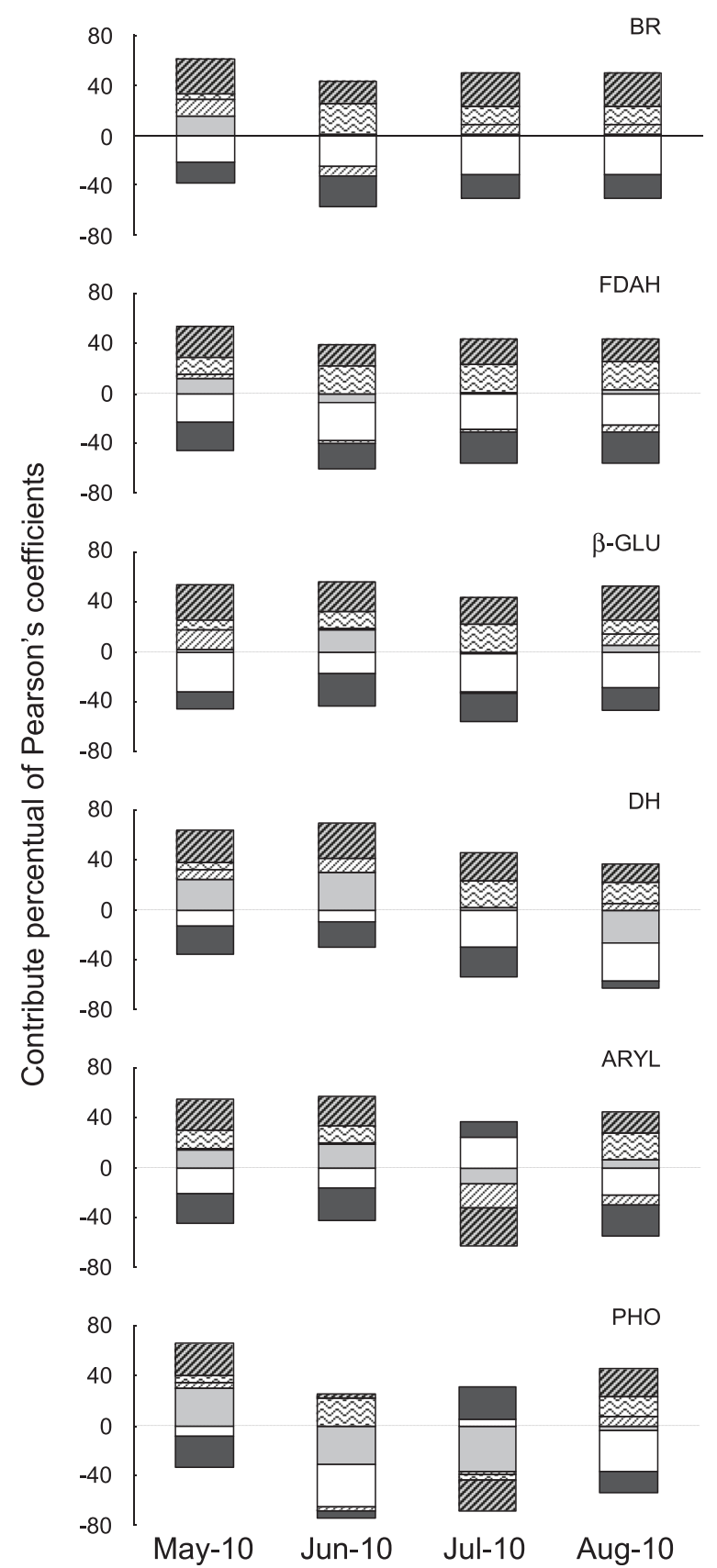

Figure 6 Cumulative regression coefficient profiles produced by cross-correlating soil activities with compost ${ }^{13} \mathrm{C}$-CPMAS-NMR regions.
Although the ${ }^{13} \mathrm{C}$-CPMAS-NMR spectra of composted materials indicated an overall similar $\mathrm{C}$ distribution, the analysis of specific signals exhibited clear differences in molecular composition. The $\mathrm{C}_{1}$ and $\mathrm{C}_{2}$ on-farm composts were characterized not only by cellulosic polysaccharides but also by prominent signals at 30, 56 and
$152 \mathrm{ppm}$, thereby revealing significant amounts of both alkyl components and lignin derivatives. This finding suggests that the inclusion of larger initial rates of stabilizing lignocellulosic materials, represented by wood chips, promoted the incorporation of stable and recalcitrant organic components. Conversely, the NMR spectra of the $\mathrm{C}_{3}$ compost, showed a lower content of hydrophobic alkyl and aromatic compounds and a corresponding relative increase of more biolabile $\mathrm{O}$-alkyl $\mathrm{C}$ components. Among the on-farm composts, evidently different characteristics were found in the $C_{4}$ sample, which was made with the initial larger amount of tomato residues. Unlike the previous composts, in addition to the peak at $30 \mathrm{ppm}$, many distinct signals were shown in the broad alkyl-C region (0 to $45 \mathrm{ppm}$ ), thus suggesting the simultaneous presence of different alkyl chains from linear and branched fatty acids and peptidic derivatives [14]. The inconsistency between the sharp intense peaks shown at $56 \mathrm{ppm}$, as compared to the low abundance of the O-aromatic lignin components in the 148 to 155 interval, also suggested the large contribution of peptidic moieties to the global resonance in the 46 to $60 \mathrm{ppm}$ region, as also indicated by the larger $\mathrm{N}$ content found in the $\mathrm{C}_{4}$ compost. Furthermore, the permanence of biolabile organic compounds was stressed by the peaks positioned at 43 and $98 \mathrm{ppm}$ assigned, respectively, to $\mathrm{C} \alpha$ and $C \beta$ of amino acids [15] and to $C 1$ carbon of monosaccharides components [10]. Lastly, the $C$ distribution found in the NMR spectra of the commercial $\mathrm{C}_{\mathrm{OW}} \mathrm{com}$ post was characterized by the relative predominance of carbohydrates and alkyl-C, combined with the lowest amounts of aromatic and lignin components.

Stability is the compost property, which refers to microbial degradability of organic matter [16]. Changes in biological parameters have been indicated as reasonable and informative markers of compost stability since they shall be linkable with substrate availability for microbial growth [17]. Here, our composted residues showed increasing values of FDAH and BR according to their abundance in phenolic and aromatic- $\mathrm{C}$ and the amount of tomato residues used in feedstock. These hydrophobic moieties could be responsible for the maintenance of an unstable carbon reservoir formed by predominating alkyl-C and lignin-deriving compounds which was still subjected to microbial breakdown. These labile carbon pools, possibly, had already been widely removed in the commercial compost.

\section{Effects of on-farm compost on plant growth and productivity}

Plant growth sustainability by compost refers to its quality and potential for agricultural applications [18]. Since this property, indicated as compost maturity, is closely linked to the loss of phytotoxicity [19], it can be directly 
CTRL $\mathrm{M}_{\mathrm{NR}} \Delta \mathrm{M}_{\mathrm{LR}} \quad \mathrm{C}_{1} \quad \mathrm{OC}_{2} \Delta \mathrm{C}_{3} \diamond \mathrm{C}_{4} \square \mathrm{C}_{\mathrm{OW}}$
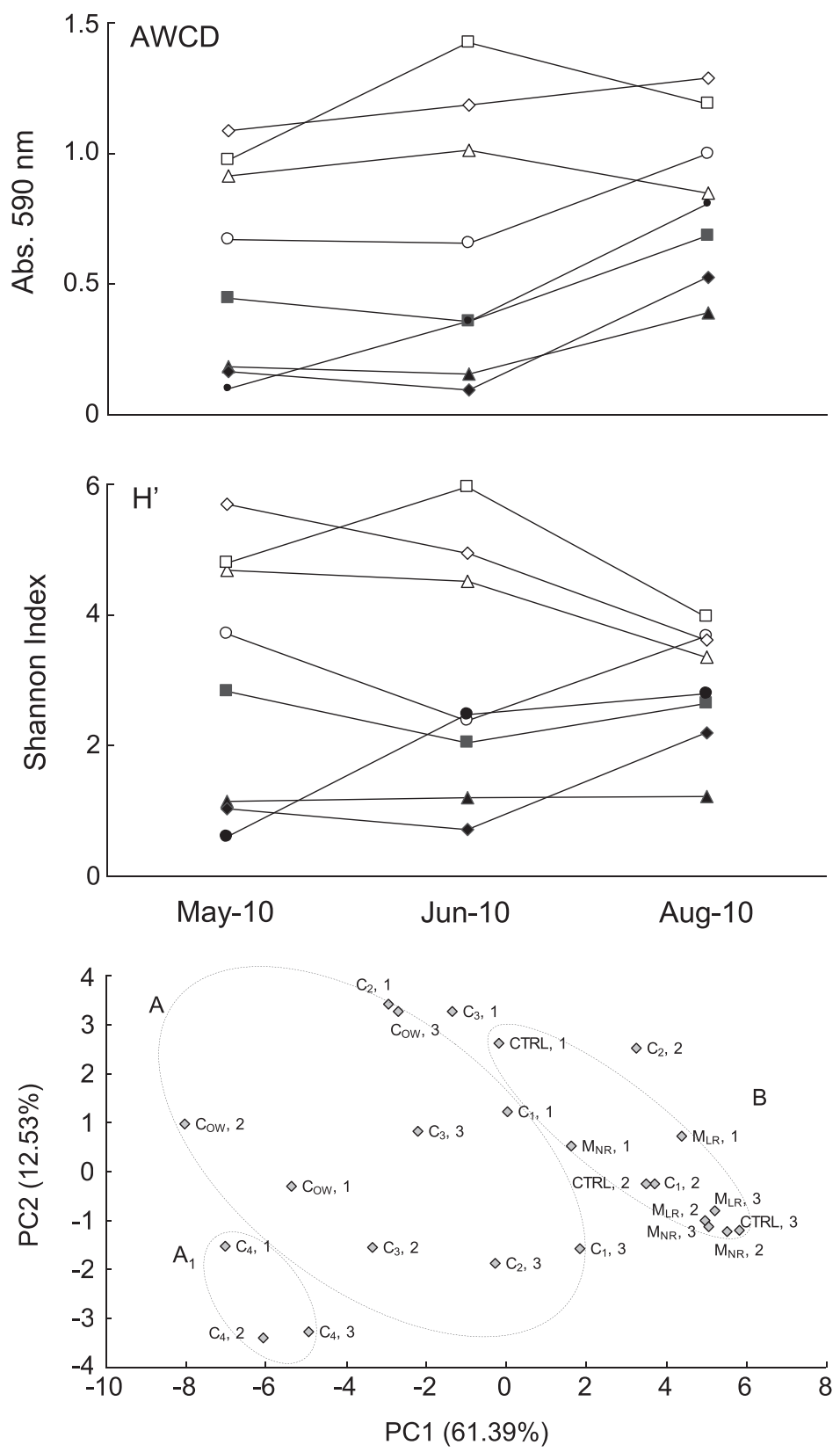

Figure 7 Changes in soil Biolog metabolic activity (AWCD), Shannon Index ( $\left.\mathrm{H}^{\prime}\right)$ and biplot PCA distribution of CLPPs. They were assessed in experimental plots after soil treatments at three time points of incubation.

assessed by evaluating the effects of compost eluates on seed germination [20]. In the current study, cress germination assay showed GI\% levels exceeding the threshold value of $80 \%$, which is indicative of mature and phytotoxin-free composts [21,22]. In some cases, further diluted compost extracts could have stimulate seed germination. Likely, this could be due to organic molecules dissolved into compost water-extractable fractions, that provide seedling development promotion [22]. However, the detection and the individuation of this kind of molecules from our on-farm composts, needs of further investigations and could be an interesting future perspective of the current research. Growth stimulation effects also may occur thank to the compost humic fraction that, for 
example, could be responsible for root proliferation $[23,24]$. The productive response of the plants to composts may involve firstly nutrient supply and induction of well growth conditions till ripening. Here, tomato yield was observed significantly increased at levels of minerally fertilized plots, under $\mathrm{C}_{4}$ amendment, as compared to the untreated soil. $\mathrm{C}_{\mathrm{OW}}$, instead, although was the most nutrient-richest compost, leads to lowest yields because of the initial detrimental impact on the plants. These findings suggest that the nutritional value alone cannot totally explain the agronomic performances of the composts. But, other factors, such as the absence of phytotoxicity [25], the activation of soil useful microorganisms [26] or disease suppressiveness mechanisms, improvement of soil physical propriety, should be totally considered. Remarkable reduction in crop yield under plant stress due to phytotoxic composts has been widely reported [27]. Furthermore, as development of this work, the extraction and characterization of humic water-extractable fraction in composted samples could contribute to clarify these aspects.

In the current study, the antifungal activity showed by composts against $F$. oxysporum f. sp. lycopersici indicated, in addition, their suppressive potential, which was not possible confirm in the field since, under natural conditions, tomato wilt disease did not occurred. Anyhow, a previous study showed that some of these tomato on-farm composts $\left(C_{1}\right.$ and $\left.C_{4}\right)$ and $C_{\text {OW }}$ significantly suppressed soil-borne diseases caused by Rhizoctonia solani and Sclerotinia minor and suppressiveness were related to their chemical characteristics and ${ }^{13} \mathrm{C}$-CPMAS-NMR spectra [28]. Accordingly, Yogev et al. [29] reported the ability of composted tomato plants, to suppress Fusarium wilt on melon.

\section{Effects of on-farm compost on soil biological activities} Compost amendments represent an extraordinary food event for soil microbes that play a crucial role in the turnover of all major plant nutrients. Soil biota, in fact, is involved in the SOM cycle by activating specific enzymatic pathways, through which complex carbon structures are transformed into simple organic and inorganic molecules that can be taken up by plants. External carbon supplies, such as compost additions, cause substantial shifts in SOM chemical composition and soil biological activity profiles [30]. These changes can be followed by monitoring the evolution overtime of soil quality indicators, such as microbiological and biochemical parameters [31]. The respiration rate reflects the instantaneous microbial activation induced by labile-C compounds [30]. In this study, the BR pattern was similar to those described previously by Pane et al. [26] and Cytrin et al. [32] with an initial burst of activity induced by compost, followed by a significant decrease approaching levels of the not- amended soil. In fact, fluorescein degradation due to generalist enzymes, such as proteases, lipases and esterases [33], $\beta$-glucosidase and dehydrogenase, exhibited time-shifted trends. The kinetics of these enzymes are closely related to microbial polysaccharide breakdown with the release of low molecular weight organic compounds [31] and organic matter oxidation [34]. Biolog CLPPs showed prolonged changes in microbial structures due to compost supply and were observed over incubation time, as indicated by PCA analysis. More specific enzymatic activities, such as phosphatase, which hydrolyze organic P into phosphates and arylsulphatase, which hydrolyze aromatic sulphate esters into phenols and sulphate [35] showed, instead, different behaviours. Response of soils to amendment may be affected by the molecular quality of composts. The levels of soil activity were found positively related to NMR aromatics and polysaccharides over time, suggesting the involvement of these hydrophobic moieties in the modulation of the labile carbon flux for microbial activation. Phenolic-C passes from negative to positive correlation when sulphatase and phosphatase were strongly induced in soils. A number of previous studies highlighted the role of phenolic SOM in the regulation of soil enzymatic activities [36-38]. Jindo et al. [39] reported the up-regulation of phosphatase and other enzymes in biochar-blended composts, concomitantly to increases in lignin polyphenol oxidation. Accordingly, Grandy et al. [37] and Leinweber et al. [38] found that strong predictive character of oxidation and the depletion rates of plant-derived lignins on the intensity of microbial transformations occurred both in less degraded systems, such as forest ecosystems, as well as in secular cropped lands. Here, on-farm composts were rich in lignin-derived compounds thanks to the large contribution of plant residues. Lignin is a relatively stable constituent of SOM that can support a long-lasting broadspectrum soil microbial activity [40]. In the present work, solid state ${ }^{13} \mathrm{C}$-CPMAS-NMR spectroscopy revealed differences in NMR resonance signals characteristic for alkyl C (0 to $45 \mathrm{ppm})$ and aromatic C (111 to $145 \mathrm{ppm}$ ) among composts that may explain the differences in induced microbiological soil activities. The alkyl $\mathrm{C}$ spectral region includes the aliphatic macromolecular biolipids that were reported as typical biomarkers in green waste-derived composts [41]. Instead, the aromatic $C$ type includes peaks at $152 \mathrm{ppm}$ (O-substituted $\mathrm{C}$ in guaiacyl and syringyl units) and $130 \mathrm{ppm}$ (unsubstituted $C$ in $p$-hydroxy phenyl rings of cinnamic units in both lignin and suberin biopolymers) and indicates that the main components of these composts are just lignocellulosic-derived molecules and hydrophobic alkyl moieties [9]. Therefore, it is possible that these lignin residues can affect indirectly biological soil properties by prolonging carbon availability to microbes over time. 


\section{Chemical analyses and ${ }^{13} \mathrm{C}-\mathrm{CPMAS}-\mathrm{NMR}$ spectroscopy of compost samples}

Total $N$ was determined according to the Kjeldahl method. The contents of $\mathrm{P}, \mathrm{Ca}, \mathrm{K}, \mathrm{Mg}, \mathrm{Na}, \mathrm{Cd}, \mathrm{Cr}, \mathrm{Cu}$, $\mathrm{Mn}, \mathrm{Pb}$ and $\mathrm{Zn}$ were determined, after compost acid digestion with a microwave oven, by ICP-OES (iCAP 6000 Series, Thermo Scientific. Waltham, MA, USA). The water content of the composts was determined after drying at $105^{\circ} \mathrm{C}$ for $72 \mathrm{~h}$. Compost water-holding capacity was determined by measuring water content held against gravity in a filter-paper-lined funnel. Electrical Conductivity (EC) and $\mathrm{pH}$ were determined according to the official methods of the Italian National Society of Soil Science [42].

Molecular distribution of compost organic carbon was evaluated by ${ }^{13} \mathrm{C}$-CPMAS-NMR spectroscopy. The ${ }^{13} \mathrm{C}$ CPMAS-NMR spectra were obtained with a Bruker AVANCE $^{\mathrm{TM}} 300$ (Bruker BioSpin GmbH, Rheinstetten, Germany), equipped with a 4-mm wide bore MAS probe, operating at a ${ }^{13} \mathrm{C}$ resonating frequency of $75.475 \mathrm{MHz}$. Compost samples (100 to $150 \mathrm{mg}$ ) were packed in 4-mm zirconia rotors with Kel-F caps and spun at $13 \pm 1 \mathrm{kHz}$. To account for possible inhomogeneity of the Hartmann-Hahn condition at high rotor spin rates, a $1 \mathrm{H}$ ramp sequence was applied in $\mathrm{CP}$ experiments during a contact time (CT) of $1 \mathrm{~ms}$. The ${ }^{13} \mathrm{C}$-CPMAS experiments implied a collection of 6,000 scans with 2,266 data points over an acquisition time of $25 \mathrm{~ms}$ and a recycle delay of $2.0 \mathrm{~s}$. The Bruker Topspin 1.3 software was used to collect and process the NMR spectra. All free induction decays (FIDs) were transformed by applying a $4 \mathrm{k}$ zero filling and a line broadening of $100 \mathrm{~Hz}$. The areas for different ${ }^{13} \mathrm{C}$ resonances were assigned according to previous reports $[4,28,43]$ into six integrating regions as follows: 0 to $45 \mathrm{ppm}$ (alkyl C), 46 to 60 ppm (methoxyl C), 61 to 110 ppm (O-alkyl C), 111 to 145 ppm (aromatic C or aryl C), 146 to 165 ppm (phenolic C or O-aryl C) and 166 to 195 ppm (carboxylic C). The area of each spectral region was divided by the sum of all spectral areas in order to obtain a relative percentage.

\section{Basal respiration, FDA hydrolysis and phytotoxicity of compost samples}

$\mathrm{BR}$ and FDAH were measured with a modification of method described by Pane et al. [44]. Basal respiration was from a compost (50-g dry weight) wetted with water up to $80 \%$ of its water-holding capacity and placed in a jar $(500 \mathrm{ml})$ with an airtight cap. Released $\mathrm{CO}_{2}$ was measured using a $\mathrm{CO}_{2}$ Analyser IRGA SBA-4 OEM (PP Systems, USA).

To evaluate fluorescein diacetate (FDA) hydrolysis, $2.5 \mathrm{~g}$ of compost was mixed with $15 \mathrm{ml}$ of $0.2 \mathrm{M}$ potassium phosphate buffered at $\mathrm{pH} 7.6$, followed by the addition of $0.5 \mathrm{ml} \mathrm{FDA} \mathrm{solution}\left(2 \mathrm{mg} \mathrm{ml}^{-1}\right)$. The mixture was shaken for $2 \mathrm{~h}$ in an orbital incubator and the hydrolysis reaction stopped by adding $15 \mathrm{ml} \mathrm{CHCl}_{3}$ /
$\mathrm{CH}_{3} \mathrm{OH}(2: 1 v / v)$. The reaction mixture was centrifuged $(700 \times g)$ and the absorbance of the aqueous supernatant measured at $490 \mathrm{~nm}$.

Composts water extracts (CWEs), prepared by vigorously shaking, were assessed for possible phytotoxicity by measuring germination and root elongation of cress (Lepidium sativum L. cv. Comune) under CWE treatments [45], as compared to the control $\mathrm{H}_{2} \mathrm{O}$. Experiments comprised three different CWE concentrations $\left(50,16.6\right.$ and $\left.5 \mathrm{~g} \mathrm{l}^{-1}\right)$ replicated 10 times. The number of seeds germinated and root length were recorded after $36 \mathrm{~h}$ following germination. GI\% that was directly affected by phytotoxicity was then obtained by multiplying the number of germinated seeds by the relative mean root length, expressed as percentage of control accordingly to following formula [20]:

$$
\begin{aligned}
\mathrm{GI} \%= & \left(\frac{\text { No. of seeds germinated on CWEs }}{\text { No. of seeds germinated on water }}\right) \\
& \times\left(\frac{\text { Mean root length on CWEs }}{\text { Mean root length on water }}\right) \times 100
\end{aligned}
$$

\section{Assessment of in vitro suppressiveness of compost}

In order to evaluate compost suppressiveness, we used the tomato fungal pathogen $F$. oxysporum f. sp. lycopersici Sacc. isolated from symptomatic plants. This fungus was maintained on a potato dextrose agar medium and stored in the fungi collection of the CRA-Centro di Ricerca per l'Orticoltura (Pontecagnano, Italy). Raw, autoclaved $\left(122^{\circ} \mathrm{C}\right.$ for $22 \mathrm{~min}$ ) and filtered (with $0.22 \mathrm{~mm}$ sterilized millipore membrane, following bland centrifugation to precipitate suspended cells) CWEs, further diluted in water 1:10 vol., were used to evaluate the suppressive potential of composts against F. oxysporum f. sp. lycopersici, according to the well diffusion technique as developed by El-Masry et al. [46] and slightly modified by Pane et al. [47]. Compost pathogen suppression was assessed by measuring the CWE mycelial development inhibition as a percentage of growth reduction compared to the control plates.

\section{Field experimental design and plant parameters}

Filed experiments were carried out at the experimental farm of the CRA-Centro di Ricerca per l'Orticoltura, Battipaglia $\left(40^{\circ} 35^{\prime} 02^{\prime \prime} \mathrm{N}\right.$; $\left.14^{\circ} 58^{\prime} 50^{\prime \prime} \mathrm{E}\right)$, Salerno, Italy, on a clay loam soil (8.8-g organic $\mathrm{C} \mathrm{kg}^{-1}, 1.0 \mathrm{~g}$ Kjeldahl $\mathrm{N} \mathrm{kg}^{-1}, \mathrm{pH} 7.4,34.6 \%$ sand, $36 \%$ silt, $29.4 \%$ clay, in the top 0 - to $0.40-\mathrm{m}$ soil layer) and the experimental design adopted was a complete randomized block with three replicates, each consisting of a plot area of $25 \mathrm{~m}^{2}$. Eight soil treatments were compared: on-farm composts $\left(\mathrm{C}_{1}\right.$, $\mathrm{C}_{2}, \mathrm{C}_{3}$ and $\mathrm{C}_{4}$ ) and municipal organic waste compost $\left(\mathrm{C}_{\mathrm{OW}}\right)$ amendments, mineral normal release $\left(\mathrm{M}_{\mathrm{NR}}\right)$ and 
mineral low release $\left(\mathrm{M}_{\mathrm{LR}}\right)$ nitrogen fertilizers; untreated plots (without any fertilizers and amendment) were used as the reference control (CTRL). Composts were applied at a rate of $30 \mathrm{t} \mathrm{ha}^{-1}$ dry weight according to previous works $[48,26] . \mathrm{M}_{\mathrm{NR}}$ and $\mathrm{M}_{\mathrm{LR}}$ consisted of the application of NPK synthetic fertilizers $\left(N=150 \mathrm{~kg} \mathrm{ha}^{-1} ; \mathrm{P}_{2} \mathrm{O}_{5}=60 \mathrm{~kg} \mathrm{ha}^{-1}\right.$; $\mathrm{K}_{2} \mathrm{O}=50 \mathrm{~kg} \mathrm{ha}^{-1}$ ), in which nitrogen was ammonium nitrate and $\mathrm{ENTEC}^{\circ} 26$ (a fertilizer containing 3,4-dimethylpyrazol phosphate, a nitrification inhibitor). Composts, PK and ENTEC $^{\circ} 26$ were incorporated into the soil, 1 week before transplanting, by rotovating, at a depth of 10 to $15 \mathrm{~cm}$. Tomato plantlets (cv. Stone) were transplanted $\left(29,000\right.$ plants $\left.\mathrm{ha}^{-1}\right)$ in double rows. During the cultivation period, plant physiological status was evaluated by assessing foliar chlorophyll contents with Minolta Chlorophyll Meter SPAD-502 (Konica Minolta Sensing INC., Japan).

At the end of the crop cycle, total and commercial production and relative percentage of discard, as well as single-berry weight, were determined on an area of about $4 \mathrm{~m}^{2}$ for each plot.

\section{Soil sampling, nitrate determination and microbial activities}

From May to August, after soil treatments, soil sampling was carried out by mixing 10 sub-samples that were taken from the top layer $(0$ to $20 \mathrm{~cm}$ ) of each plot, sieved $(2 \mathrm{~mm})$, selected and stored at $4^{\circ} \mathrm{C}$ until biological laboratory determination. Soil moisture content was determined by measuring water content after soil drying at $50^{\circ} \mathrm{C}$ until constant weight. Water-holding capacity (field capacity) was determined by measuring water content held against gravity in a filter-paper-lined funnel.

Nitrate concentration in soil was analysed on weekly collected samples by colorimetric technique using Reflectoquant ${ }^{\circ}$ strips read by a reflectometer RQflex 10 (Merck, Darmstadt, Germany).

BR and FDAH were measured as reported above for the direct measure on composts. Soil $\beta$ GLU and DH activities were determined as reported by Pane et al. [44] using 4- $p$-nitrophenyl- $\beta$-D-glucopyranoside (PNP) and 2-( $p$-iodophenyl)-3-( $p$-nitrophenyl)-5-phenyltetrazolium chloride (INT) substrates, respectively. $\beta$ GLU was determined by adding $0.35 \mathrm{~g}$ of soil sample to $2 \mathrm{ml}$ of $0.05 \mathrm{M}$ maleate buffer, $\mathrm{pH}$ 5.0. The mixture was left for $5 \mathrm{~min}$ at $30^{\circ} \mathrm{C}$, and the enzymatic reaction was started by adding $0.5 \mathrm{ml}$ of $0.2 \mathrm{mM}$ PNP. After incubation for $1 \mathrm{~h}$ at $37^{\circ} \mathrm{C}$, the reaction was stopped by adding $0.5 \mathrm{ml}$ of $0.5 \mathrm{M}$ $\mathrm{CaCl}_{2}, 2 \mathrm{ml}$ of $0.5 \mathrm{~N} \mathrm{NaOH}$ and $5 \mathrm{ml}$ of $\mathrm{H}_{2} \mathrm{O}$. After centrifugation at $1,500 \times g$ for $5 \mathrm{~min}$ at $5^{\circ} \mathrm{C}$ and after filtration of the aqueous phase, the absorbance of filtrates was measured at $398 \mathrm{~nm}$. DH was determined by adding $0.5 \mathrm{~g}$ of soil sample to $1 \mathrm{ml}$ of $0.2 \mathrm{M}$ Tris buffer, pH 5.0. The enzymatic reaction was started by adding $0.5 \mathrm{ml}$ of $0.2 \mathrm{mM}$ INT. After incubation by shaking for $48 \mathrm{~h}$ at $37^{\circ} \mathrm{C}$, the reaction was stopped by adding $10 \mathrm{ml}$ of ethanol 96\% N,N-dimethylformamide (1:1) and incubated in the dark by shaking for $1 \mathrm{~h}$ at room temperature. After centrifugation at $5,000 \times g$ for $5 \mathrm{~min}$ at $5^{\circ} \mathrm{C}$ and after filtration of the aqueous phase, the absorbance of filtrates was measured at $464 \mathrm{~nm}$. Soil PHO and ARYL activities were determined using $p$-nitrophenyl phosphate and $p$-nitrophenyl sulphate as substrate, respectively [49]. A 0.5-g soil sample was added to $2 \mathrm{ml}$ of maleate buffer, $\mathrm{pH} 6.5$. The enzymatic reaction was started by adding $0.5 \mathrm{ml}$ of $0.2 \mathrm{mM}$ substrate. After incubation by shaking for $1 \mathrm{~h}$ at $37^{\circ} \mathrm{C}$, the reaction was stopped by adding $0.5 \mathrm{ml}$ of $\mathrm{CaCl}_{2}$ and $5 \mathrm{ml} \mathrm{H}_{2} \mathrm{O}$. After centrifugation at 5,000 $\times g$ for $5 \mathrm{~min}$ at $5^{\circ} \mathrm{C}$ and after filtration of the aqueous phase, the absorbance of filtrates was measured at $398 \mathrm{~nm}$. All enzymatic analyses blanks, without addition of a reducing substrate, were also included to correct for background absorbance and the activity was determined against a calibration curve. Absorbance was measured by spectrophotometer model SpectroFlex 6600 (WTW, Oberbayern, Germany). Soil respiration and all enzymatic activities were determined on monthly sampled soils.

Biolog CLPPs were determined on soils sampled, after amendment, at beginning (May), at middle (Jun) and at end (Aug) of cropping cycle, as AWCD and $\mathrm{H}^{\prime}$ index, as previously developed by Pane et al. [44]. Aliquots of $100 \mu \mathrm{l}$ of water-extracted soil sample, at a final dilution of $10^{-4}(w / w)$, were inoculated into the Eco-microplates. These were incubated at $25^{\circ} \mathrm{C}$ for 4 days and read, $96 \mathrm{~h}$ post inoculum, at $590 \mathrm{~nm}$, using the Bio-Rad Microplate Reader 550 (Bio-Rad, Hercules, CA, USA).

\section{Statistical analysis}

Tomato agronomic data were analysed by ANOVA and means were separated by Duncan's test. The relationships among biological activities detected in the amended soils and relative quantities of molecular organic ${ }^{13} \mathrm{C}$ groups of composts were assessed using a regression analysis. Biolog AWCD profiles for single substrates were computed by principal component analysis, performed on OD data of the 31 carbon sources to assess distribution biplot of all community samples.

\section{Conclusions}

This study showed the great potential of on-farm technology to produce vegetable composts with peculiar characteristics that are different from commercial composted biosolids. Nutrition and biostimulation effects may be responsible for the increased productive response to agricultural compost amendments in cropping systems. NMR profiling showed that molecular composition of on-farm composts is responsible for microbial degradability in the soil and that phenolic $\mathrm{C}$ could play a crucial role in modulating soil biological activities. 


\section{Competing interests}

The authors declare that they have no competing interests.

\section{Authors' contributions}

$\mathrm{CP}, \mathrm{GC}$ and DV participated in composting activities and drafted the manuscript. CP participated to the field trial. DV carried out the microbiological studies. AP and RS carried out the NMR studies and drafted the manuscript. AMP carried out chemical analysis on composts and drafted the manuscript. MZ participated in design and coordination of the study and drafted the manuscript. All authors read and approved the final manuscript.

\section{Author details}

'Consiglio per la Ricerca in Agricoltura e l'Analisi dell'Economia Agraria, Centro di Ricerca per l'Orticoltura, via dei Cavalleggeri 25, I-84098 Pontecagnano, SA, Italy. ${ }^{2}$ Dipartimento Scienze dei Sistemi Colturali, Forestali e dell'Ambiente, Università degli Studi della Basilicata, viale dell'Ateneo Lucano 10, I-85100 Potenza, Italy. ${ }^{3}$ Centro Interdipartimentale di Ricerca sulla Risonanza Magnetica Nucleare per l'Ambiente, I'Agro-Alimentare ed i Nuovi Materiali (CERMANU), Via Università 100, I-80055 Portici, NA, Italy.

Received: 8 May 2014 Accepted: 5 December 2014

Published online: 11 February 2015

\section{References}

1. Maniadakis K, Lasaridi K, Manios Y, Kyriacou M, Manios T (2004) Integrated waste management through producers and consumers education: composting of vegetable crop residues for reuse in cultivation. J Environ Sci Health B 39:169-183

2. Christian AH, Evanylo GK, Pease JW (2009) On-Farm Composting - A Guide to Principles, Planning \& Operations. VCE Publ. No. 452-232.

3. Celano G, Alluvione F, Abdel Aziz M, Spaccini R (2012) The carbon dynamics in the experimental plots. Use of ${ }^{13} \mathrm{C}$ - and ${ }^{15} \mathrm{~N}$-labelled compounds for the soil-plant balance in carbon sequestration. In: Piccolo A (ed) Carbon sequestration in agricultural soils. A multidisciplinary approach to innovative methods. Springer, Düsseldorf, pp 107-144

4. Pane C, Spaccini R, Piccolo A, Scala F, Bonanomi G (2011) Compost amendments enhance peat suppressiveness to Pythium ultimum, Rhizoctonia solani and Sclerotinia minor. Biol Cont 56:115-124

5. López-Pérez JA, Roubtsova T, Ploeg A (2005) Effect of three plant residues and chicken manure used as biofumigants at three temperatures on Meloidogyne incognita infestation of tomato in greenhouse experiments. J Nematol 37:489-494

6. Avgelis AD, Manios VI (1989) Elimination of tomato mosaic virus by composting tomato residues. Neth J Plant Pathol 95:167-170

7. Ghaly AE, Alkoaik F, Snow A (2006) Inactivation of Botrytis cinerea during thermophilic composting of greenhouse tomato plant residues. Appl Biochem Biotechnol 133:59-75

8. Alkoaik F, Ghaly AE (2006) Influence of dairy manure addition on the biological and thermal kinetics of composting of greenhouse tomato plant residues. Waste Manag 26:902-913

9. Spaccini R, Mazzei P, Squartini A, Giannattasio M, Piccolo A (2012) Molecular properties of a fermented manure preparation used as field spray in biodynamic agriculture. Environ Sci Poll Res 19:4214-4225

10. De Marco A, Spaccini R, Vittozzi P, Esposito F, Berg B, Virzo De Santo A (2012) Decomposition of black locust and black pine leaf litter in two coeval forest stands on Mount Vesuvius and dynamics of organic components assessed through proximate analysis and NMR spectroscopy. Soil Biol Biochem 51:1-15

11. Spaccini R, Piccolo A (2007) Molecular characterization of compost at increasing stages of maturity. 2. Thermochemolysis-GC-MS and ${ }^{13} \mathrm{C}$-CPMAS-NMR spectroscopy. J Agr Food Chem 55:2303-2311

12. Rondeau-Mouro C, Crepeau M-J, Lahaye M (2003) Application of CP-MAS and liquid-like solid-state NMR experiments for the study of the ripeningassociated cell wall changes in tomato. Int J Biol Macromol 31:235-244

13. Bernal-Vicente A, Ros M, Tittarelli F, Intrigliolo F, Pascual JA (2008) Citrus compost and its water extract for cultivation of melon plants in green house nurseries. Evaluation of nutriactive and biocontrol effects. Biores Technol 99:8722-8728

14. Dignac MF, Knicker H, Kogel-Knabner I (2002) Effect of N content and soil texture on the decomposition of organic matter in forest soils as revealed by solid state CPMAS NMR spectroscopy. Org Geochem 33:1715-1726
15. Kumashiro KK, Ohgo K, Niemczura WP, Onizuka AK, Asakura T (2008) Structural insights into the elastin mimetic (LGGVG)6 using solid-state ${ }^{13} \mathrm{C}$ NMR experiments and statistical analysis of the PDB. Biopol 89:668-679

16. lannotti DA, Pang T, Toth BL, Elwell DL, Keener HM, Hoitink HAJ (1993) A quantitative respirometric method for monitoring compost stability. Compost Sci Util 1:52-65

17. Komilis D, Kontou I, Ntougias S (2011) A modified static respiration assay and ist relationship with an enzymatic test to assess compost stability and maturity. Biores Technol 102:5863-5872

18. Som MP, Lemée L, Amblès A (2009) Stability and maturity of a green waste and biowaste compost assessed on the basis of a molecular study using spectroscopy, thermal analysis, thermodesorption and thermochemolysis. Biores Technol 100:4404-4416

19. Raj D, Antil RS (2011) Evaluation of maturity and stability parameters of composts prepared from agro-industrial wastes. Biores Technol 102:2868-2873

20. Tiquia SM, Tam NFY (1998) Elimination of phytotoxicity during co-composting of spent pig-manure sawdust litter and pig sludge. Biores Technol 65:43-49

21. Zucconi F, Pera A, Forte M, de Bertoldi M (1981) Evaluating toxicity of immature compost. BioCycle 22:54-57

22. Tiquia SM, Tam NFY, Hodgkiss IJ (1996) Effects of composting on phytotoxicity of spent pig-manure sawdust litter. Environ Poll 93:249-256

23. Arancon NQ, Lee S, Edwards CA, Atiyeh RM (2003) Effects of humic acids derived from cattle, food and paper-waste vermicomposts on growth of greenhouse plants. Pedobiologia 47:741-744

24. Atyeh RM, Lee S, Edwards CA, Arancon NQ, Metzger JD (2002) The influence of humic acids derived from earthworm-processed organic wastes on plant growth. Biores Technol 84:7-14

25. Levy JS, Taylor BR (2003) Effects of pulp mill solids and three composts on early growth of tomatoes. Biores Technol 89:297-305

26. Pane C, Villecco D, Zaccardelli M (2013) Short-time response of microbial communities to waste compost amendment of an intensive cultivated soil in Southern Italy. Comm Soil Sci Plant Anal 44:2344-2352

27. Woodbury PB (1992) Trace elements in municipal solid waste composts: a review of potential detrimental effects on plants, soil biota, and water quality. Biomass Bioenerg 3:239-259

28. Pane C, Piccolo A, Spaccini R, Celano G, Villecco D, Zaccardelli M (2013) Agricultural waste-based composts exhibiting suppressivity to diseases caused by the phytopathogenic soil-borne fungi Rhizoctonia solani and Sclerotinia minor. Appl Soil Ecol 65:43-51

29. Yogev A, Raviv M, Hadar Y, Cohen R, Katan J (2006) Plant waste-based composts suppressive to diseases caused by pathogenic Fusarium oxysporum. Eur J Plant Pathol 116:267-278

30. Tejada M, Gonzales JL, García-Martínez AM, Parrado J (2008) Application of a green manure and green manure composted with beet vinasse on soil restoration: effects on soil properties. Biores Technol 99:4949-4957

31. Serra-Wittling C, Houot S, Barriuso E (1996) Soil enzymatic response to addition of municipal solid-waste compost. Biol Fert Soils 20:226-236

32. Cytryn E, Kautsky L, Ofek M, Mandelbaum RT, Minz D (2011) Short-term structure and functional changes in bacterial community composition following amendment with biosolids compost. Appl Soil Ecol 48:160-167

33. Schnürer L, Rosswall T (1982) Fluorescein diacetate hydrolysis as a measure of total microbial activity in soil and litter. Appl Environ Microbiol 43:1256-1261

34. Fernández P, Sommer I, Cram S, Rosas I, Gutiérrez M (2005) The influence of water-soluble $\mathrm{As}(\mathrm{III})$ and $\mathrm{As}(\mathrm{V})$ on dehydrogenase activity in soils affected by mine tailings. Sci Tot Environ 348:231-243

35. Makoi JHJR, Ndakidemi PA (2008) Selected soil enzymes: examples of their potential roles in the ecosystem. Afr J Biotechnol 7:181-191

36. Fenner N, Freeman C, Reynolds B (2005) Observations of a seasonally shifting thermal optimum in peatland carbon-cycling processes; implications for the global carbon cycle and soil enzyme methodologies. Soil Biol Biochem 37:1814-1821

37. Grandy AS, Neff JC, Weintraub MN (2007) Carbon structure and enzyme activities in alpine and forest ecosystems. Soil Biol Biochem 39:2701-2711

38. Leinweber P, Jandl G, Baum C, Eckhardt KU, Kandeler E (2008) Stability and composition of soil organic matter control respiration and soil enzyme activities. Soil Biol Biochem 40:1496-1505

39. Jindo K, Suto K, Matsumoto K, García C, Sonoki T, Sanchez-Monedero MA (2012) Chemical and biochemical characterisation of biochar-blended composts prepared from poultry manure. Biores Technol 110:396-404 
40. Tuomela M, Vikman M, Hatakka A, Itävaara M (2000) Biodegradation of lignin in a compost environment: a review. Biores Technol 72:169-183

41. Zmora-Nahum S, Hadar Y, Chen Y (2007) Physico-chemical properties of commercial composts varying in their source materials and country of origin. Soil Biol Biochem 39:1263-1276

42. Violante P (2000) Metodi di Analisi Chimica del Suolo, Angeli, F. (Eds.), pp. 536

43. Mathers NJ, Jalota RK, Dalal RC, Boyd SE (2007) ${ }^{13}$ C NMR analysis of decomposing litter and fine roots in the semi-arid Mulga Lands of southern Queensland. Soil Biol Biochem 39:993-1006

44. Pane C, Villecco D, Pentangelo A, Lahoz E, Zaccardelli M (2012) Integration of soil solarization with Brassica carinata seed meals amendment in a greenhouse lettuce production system. Acta Agric Scand Sect B Soil Plant Sci 62:291-299

45. Bonanomi G, Del Sorbo G, Mazzoleni S, Scala F (2007) Autotoxicity of decaying tomato residues affects tomato susceptibility to Fusarium wilt. J Plant Pathol 89:219-226

46. El-Masry MH, Khalil Al, Hassouna MS, Ibrahim HAH (2002) In situ and in vitro suppressive effect of agricultural composts and their water extracts on some phytopathogenic fungi. World J Microb Biot 18:551-558

47. Pane C, Celano G, Villecco D, Zaccardelli M (2012) Control of Botrytis cinerea, Alternaria alternata and Pyrenochaeta lycopersici on tomato with whey compost-tea applications. Crop Prot 38:80-86

48. Zaccardelli M, Perrone D, Del Galdo A, Giordano I, Villari G, Bianco M (2006) Multidisciplinary approach to validate compost use in vegetable crop systems in Campania Region (Italy): effect of compost fertilization on processing tomato in field cultivation. Acta Hort 700:285-288

49. Stege PW, Messina GA, Bianchi G, Olsina RA, Raba J (2009) Determination of arylsulphatase and phosphatase enzyme activities in soil using screenprinted electrodes modified with multi-walled carbon nanotubes. Soil Biol Biochem 41:2444-2452

\section{Submit your manuscript to a SpringerOpen ${ }^{\circ}$ journal and benefit from:}

- Convenient online submission

- Rigorous peer review

- Immediate publication on acceptance

- Open access: articles freely available online

- High visibility within the field

- Retaining the copyright to your article

Submit your next manuscript at $>$ springeropen.com 